\title{
Water and sediment discharge from a large surging glacier: Bering Glacier, Alaska, U.S.A., summer 1994
}

\author{
Yann Merrand and Bernard Hallet \\ Quaternary Research Center and Department of Geological Sciences, University of Washington, Box 351360, \\ Seattle, WA 98195-1360, U.S.A.
}

\begin{abstract}
The water and sediment output from Vitus Lake, in front of Bering Glacier, was monitored starting in July 1994. Instrumentation was placed in the lake outlet to record stage, turbidity, conductivity and temperature and velocity of flow of river water. Two outburst floods punctuated the termination of the 1993-94 Bering Glacier surge in August 1994. The better-documented flood lasted about $10 \mathrm{~d}$, during which the flood discharge averaged $1100 \mathrm{~m}^{3} \mathrm{~s}^{-1}$, in excess of normal discharge $\left(1550 \mathrm{~m}^{3} \mathrm{~s}^{-1}\right)$ during this part of the ablation season, and about $9.5 \times 10^{8} \mathrm{~m}^{3}$ of water drained from Bering Glacier. The excess water volume discharged during this flood corresponds to a $0.4 \mathrm{~m}$ thick layer of water extending over the $2500 \mathrm{~km}^{2}$ of Bering Glacier that was surging in early summer. The suspended-sediment flux from Vitus Lake during the summer of 1994 was two orders of magnitude less than rates of sediment production by other fast-moving glaciers in southern Alaska. This implies that most of the sediment produced is being stored in Vitus Lake, under the glacier, or in both locations.
\end{abstract}

\section{INTRODUCTION}

A number of outstanding issues in the Earth sciences can be addressed by studying sediment production from glaciers and ice sheets. These issues include the role of sediment in glacier dynamics, the characteristics of subglacial hydraulic systems and the processes of erosion, sediment transport and deposition.

Sediment production by active glaciers is also of interest to a wide scientific audience in the broad context of the poorly understood linkages between topography, tectonics and climate. How erosive are glaciers when compared with other denudational agents (Harbor and Warburton, 1993; Hallet and others, 1996)? What is their role in mass transfer at the Earth surface, particularly in tectonically active glacierized areas? These questions, which are fundamental to our understanding of the evolution of mountain ranges and of late Cenozoic history (Molnar and England, 1990; Raymo and Ruddiman, 1992), provide the motivational framework for the study we introduce here.

Due to extreme precipitation and relief, as well as its proximity to the ocean, the St Elias Range of southern coastal Alaska, U.S.A., is the most extensively glacierized active tectonic margin on Earth. It constitutes a natural laboratory of glacially dominated surficial processes at moderately high latitude where the temperate nature of the ice permits sliding, fluvial activity, erosion and deposition. An outstanding record of sedimentation in fjords over the last century indicates that sediment yields from many tide-water glaciers in the area are an order of magnitude greater than those found in other alpine regions (e.g. Powell and Molnia, 1989; Hallet and others, 1996). Such high yields probably reflect a decrease in sediment storage in the basins since the Little Ice Age advance, as well as rapid erosion. Based on latePleistocene marine terrace uplift rates (e.g. Plafker and others, 1980), regional erosion rates on the order of 1 $10 \mathrm{~mm} \mathrm{a}^{-1}$ could have been sustained since the onset of tide-water glaciation in southern Alaska $5 \times 10^{6}$ years ago (Lagoe and others, 1993).

We are particularly interested in Bering Glacier because of the exceptional opportunity it offers to construct a sediment budget for a large glacierized drainage basin. With a $5200 \mathrm{~km}^{2}$ drainage area, Bering Glacier is the largest temperate glacier in the world (Viens, 1995). It is also dynamic and has received considerable scientific attention because, during its 1993-94 surge, ice velocities across its $25 \mathrm{~km}$ wide terminus approached $100 \mathrm{~m} \mathrm{~d}^{-1}$. It advanced up to $9 \mathrm{~km}$ into proglacial Vitus Lake within one year Molnia and others, 1994a), and anomalous crevassing marked up to $2500 \mathrm{~km}^{2}$ of the glacier surface (Molnia, 1993). Sediment production from Bering Glacier should therefore reflect a wide range of basal conditions, lithological assemblages and ice velocities. Sediment contributions from nonglacial processes are unlikely to confound significantly the sediment production from Bering Glacier, because the entire basin is ice-covered except for a few high ridges.

Another factor makes Bering Glacier ideal for developing a sediment budget: the glacier drains into Vitus Lake, which forms an effective sediment trap with only one active outlet to the ocean, the Seal River. As we are primarily interested in a long-term sediment budget, 
our task reduces to determining the net rate at which sediment enters, is deposited in, and leaves Vitus Lake during an entire surge/non-surge cycle ( $\sim 20$ years). The sediment volume deposited in the lake can be determined from the amount of accumulation between the 1967 surge and 1991 when a United States Geological Survey (USGS) team conducted seismic profiling in Vitus Lake (Carlson and others, 1993). Additional seismic data were obtained just prior to the current surge in 1993. These data will provide a timely base line for comparison with seismic profiles that are planned for the anticipated postsurge retreat of Bering Glacier from Vitus Lake.

There is little doubt that the bulk of the sediment produced by Bering Glacier is trapped in Vitus Lake, but some fraction can leave the lake, traveling via the Seal River to the Gulf of Alaska (Fig. 1). In addition to the coarse sediment that would naturally settle in any proglacial lake, fine-grained sediment also appears to be trapped, in part because the relatively saline waters of Vitus Lake tend to cause clay and silt-sized particles to flocculate. Hence, the Seal River is usually not turbid, particularly during non-surge cycles when $\sim 10 \mathrm{~km}$ of open water separates the glacier front from the outlet of Vitus Lake. During surges, however, as the floating ice terminus closes in the lake, considerable suspended sediment is transported in the Seal River to the Gulf of Alaska (Fig. 1), as evidenced by observation of highly turbid waters in the Seal and distinct sediment plumes that extend into the Gulf of Alaska (Molnia, 1993).

A long-term sediment budget for Bering Glacier would be incomplete without determination of the rate of leakage of sediment from Vitus Lake via the Seal River. Hence, in July 1994, we initiated a study of sediment and water fluxes via the Seal during the recent surge. In this paper, we present initial results from this study. Compared to modern studies of proglacial streams, typically conducted in $\sim 1-10 \mathrm{~km}^{2}$ basins (e.g. Gurnell, 1987; Bogen, 1989; Lawler and others, 1992), our flux estimates are crude because they are limited to a single summer, and essentially to one site. However, our data are of interest because they provide the best available record of massive floods that punctuated the termination of the spectacular 1993-94 surge. They also provide a measure of the sediment flux in the Seal River. Furthermore, we stress from the point of view of the long-term sediment budget of Bering Glacier that a rough estimate of sediment flux in the Seal River is entirely adequate because, as we will discuss later, this sediment leakage from Vitus Lake is small, most probably only a few per cent of the anticipated rate of sediment delivery to Vitus Lake during this surge period.

\section{FIELD SITE AND METHODS}

The Seal River is a tidal channel $8 \mathrm{~km}$ long, 200-300 m wide and $5-10 \mathrm{~m}$ deep. Whereas the narrower upper channel reach and its banks are partly armored by a lag of 0.1-1 m diameter boulders and a few larger ones, the bed of the lower reach is sandy. The upper channel planform has presumably been relatively stable since it is incised in late-Holocene drifts (Molnia and others, 1994b). In contrast, the lower part has migrated through unconsolidated eolian deposits and wave-cut platforms. As the surface of Vitus Lake is within 1-2 $\mathrm{m}$ of sea level, the influence of tides on the river and on salt-water intrusion into Vitus Lake is controlled in part by lakewater level and thus by meltwater output from the glacier. At the ocean, the amplitude of tidal variation in the 1994 summer approached $3 \mathrm{~m}$; at the lake, it was $0.5 \mathrm{~m}$.

In early July 1994, a site on the Seal River was

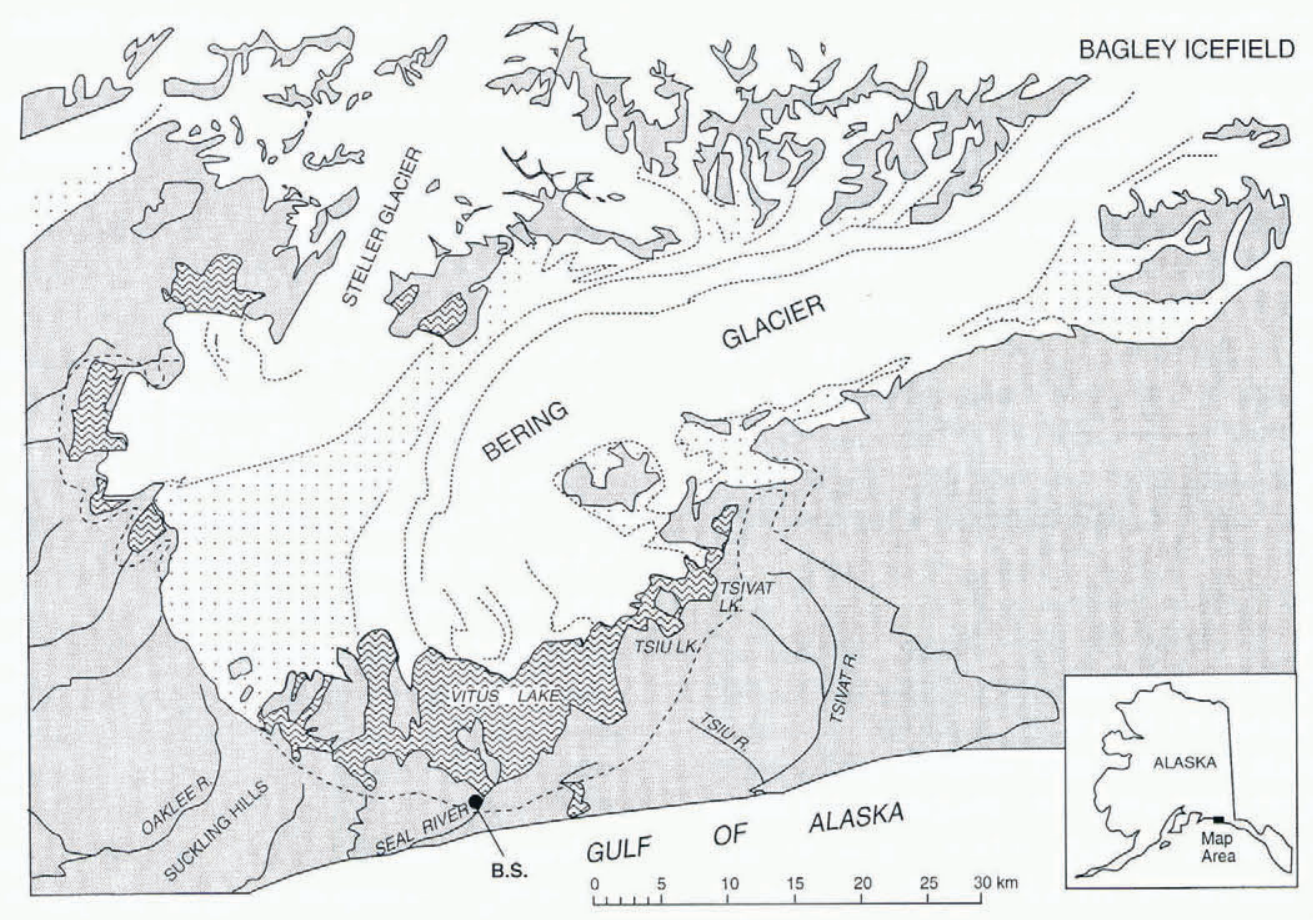

Fig. 1. Bering Glacier and Vitus Lake before the 199394 surge. Label BS refers to location of automated monitoring station on the west bank of the Seal River. Dotted pattern on glaciers represents debris-covered ice and folded moraines. 
selected for installation of an automated monitoring station for water and sediment characteristics. Icebergs streaming out of the lake during ebb tide forced us to locate our instrumentation on a large glacial erratic $700 \mathrm{~m}$ downstream from Vitus Lake (a big schist erratic, referred to as BS from now on) on the west bank of the upper channel (a $215 \mathrm{~m}$ wide cross-section at that point). Forty-five surface water samples were manually collected at BS over 10 days in July and a few days in September. A similar number of surface samples was collected episodically in the lake, in a transect across the river and at the outlet to the ocean. Sediment concentrations were obtained from 90 water samples; $100 \pm 1 \mathrm{ml}$ aliquots were filtered through $0.3 \mu \mathrm{m}$ fiber membranes, dried and weighed. Low and high discharges were each calculated from 21 spot measurements of velocity at depths of 0.2 and 0.8 of the total water depth, by J. Gray and R. Hart of the USGS on a traverse across from BS, using a Price AA current meter. During discharge measurements, the river cross-section was surveyed, and depth-integrated water samples were collected from a boat, using a Van Dorn bottle.

Hourly measurements of water turbidity, conductivity, stage, temperature and speed of flow were recorded from 17 July 1994. Most of the methods used in this study have been described extensively elsewhere, notably by Humphrey and others (1986). Proglacial environments are harsh on sensitive instrumentation, and this study experienced its share of instrument difficulties, which permitted us to obtain only rough estimates of fluxes in this very large and complex system. Although, according to initial plans, instrumentation packages to monitor water temperature, conductivity and turbidity were to be installed both at the surface and at depth, early equipment failures allowed the placement of only a single submerged package. It was placed $10 \mathrm{~m}$ from the west bank, $1 \mathrm{~m}$ above the bed in $4 \mathrm{~m}$ of water. A sonic ranger measuring water level was mounted on a boom extending over the water but was destroyed shortly after installation as heavy rains conspired with an unusually high tide to raise the river stage above expected levels. Fortunately, a pressure transducer installed near the bottom of the channel provided an independent measure of stage until 19 August 1994 when the pressure transducer abruptly went out of range and started behaving erratically; it was replaced in September 1994. The transducer was calibrated according to the manufacturer's specifications and checked for precision with stage data acquired concurrently with the highly accurate sonic ranger. The sensor resolution and accuracy correspond to stage increments of about 1 and $10 \mathrm{~cm}$ of water, respectively.

A calibration curve for the AC electrical-conductivity sensor was developed from regression between measurements using a standard conductivity meter GLA EC Instant meter) and sensor measurements in the laboratory at $\sim 20^{\circ} \mathrm{C}$. Conductivities are reported at measured temperature. No correction was attempted for temporal variations in water temperature because these were minimal, varying between $\sim 1^{\circ}$ and $2^{\circ} \mathrm{C}$. Within this range, temperature variations influence conductivity readings by at most a few per cent (Collins, 1978; Calles and Calles, 1990). Based on the quality of the calibration and the correction involved in comparing $20^{\circ} \mathrm{C}$ labora- tory data with field conductivities near $0^{\circ} \mathrm{C}$, we estimate the resolution and accuracy of our conductivity measurements to be 0.01 and $0.5 \mathrm{mS} \mathrm{cm}^{-1}$, respectively. Accordingly, temporal variations in our record of electrical conductivity, rather than absolute values, are useful in interpreting the stage record. Portions of a limited number of water samples were diluted and analyzed for major cations and anions, to aid in the interpretation of the conductivity record.

Water speed was measured by monitoring the thermal relaxation of a briefly heated thermistor, which speeds up with increasing velocity. The offset in thermistor resistance relative to its value immediately before heating decreased exponentially with time at a rate dictated by advection of heat by the flow. We describe this measurement as speed because no information is available about direction of flow, hence velocity cannot be defined. Each speed value is based on six sequential resistance measurements at $10-30$ s intervals. This sequence includes a reference value taken before excitation, which renders the measurements essentially independent of ambient water temperature. The speed sensor was calibrated in the Seal River with a hand-held Teledyne current meter. However, because of the lack of high water velocities during the calibration and the poor repeatability for the lowest velocities, the record is viewed as only a qualitative indication of local speed close to the western bank of the Seal, where mean flow directions reverse with the tides, and large-scale eddies can appear and disappear with time. As a consequence, this record is used only qualitatively to complement the stage record.

\section{RESULTS}

The influence of ocean tides on the stage of the Seal River is evident through most of the record (Fig. 2a). Despite being recorded $5 \mathrm{~km}$ up-river from the coastline, high tides at BS do not lag ocean tides; low tides also do not appear to lag, but the evidence is less clear because stage level commonly remains near minimum values for up to an hour. Three prolonged periods of relatively elevated stage can be identified over this monitoring period: (a) a broad low peak of mid-July (event A); (b) a major flood lasting approximately $10 \mathrm{~d}$ with a peak stage $1.1 \mathrm{~m}$ above normal (event B); and (c) a period of increasing stage (event C) starting on 14 August. Unfortunately, as noted above, the pressure transducer failed during event $\mathrm{C}$, and only the rising limb of the hydrograph was recorded. However, complementary evidence deduced from records of electrical conductivity and water speed (Fig. 2c and d), suggests that event $\mathrm{C}$ is similar in magnitude to, and slightly shorter in duration than, event B.

Figure 2c shows the record of local water speed with considerable variation on time-scales ranging from hours to weeks. Strong tidal forcing is evident throughout most of the record except during flood events B and C. Distinct tidal modulation can also be seen in the electricalconductivity signal (Fig. 2d) except for two intervals corresponding closely to flood events $\mathrm{B}$ and $\mathrm{C}$. The conductivity dropped from $2.7-2.8 \mathrm{mS} \mathrm{cm}^{-1}$ before flood events $\mathrm{B}$ and $\mathrm{C}$ to $1.5-1.7 \mathrm{mS} \mathrm{cm}^{-1}$ afterward. 


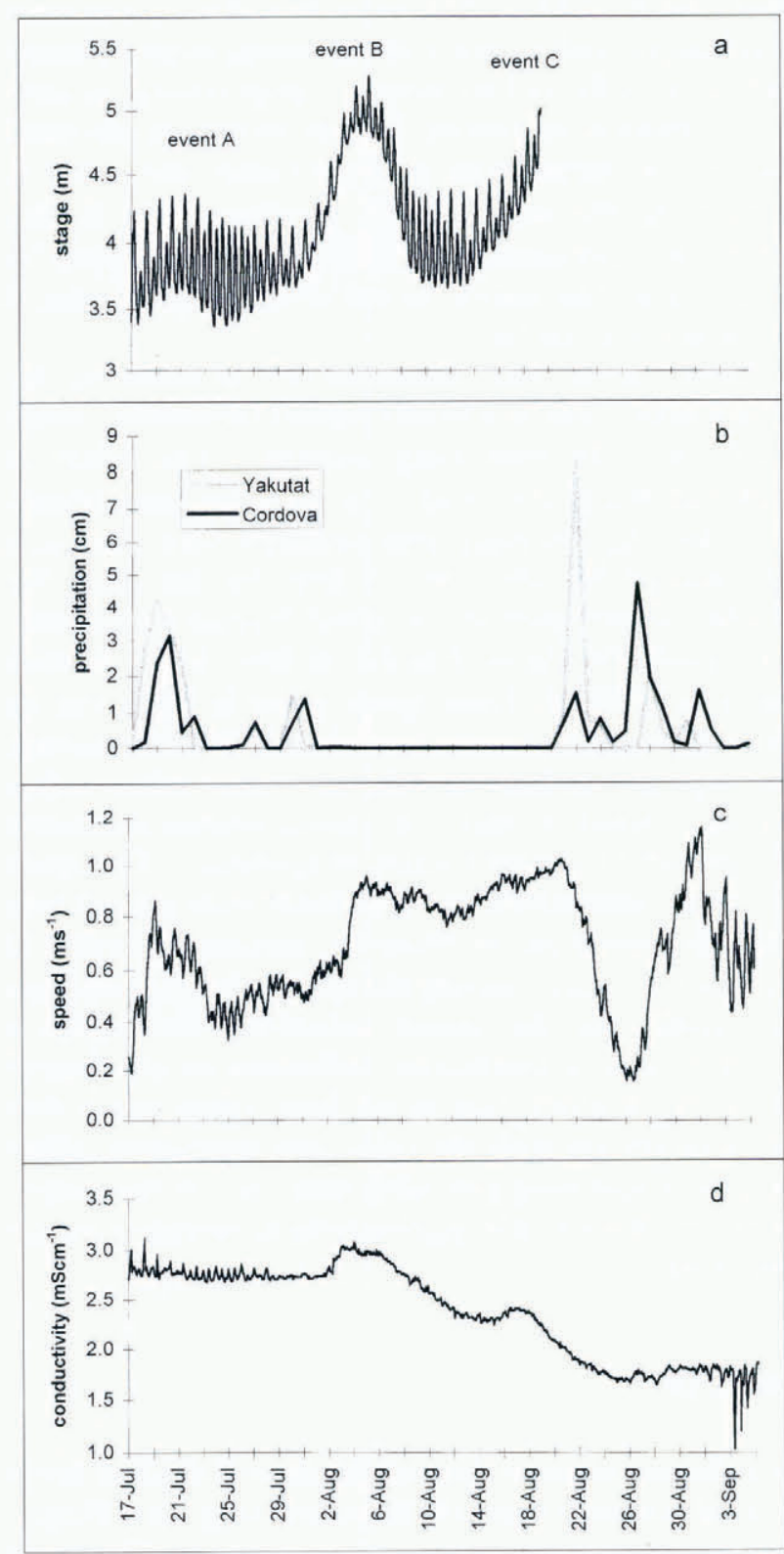

Fig. 2. 1994 summer record from BS on the Seal River. (a) Stage record with three main events ( $A, B$ and $C$ ) and tidal oscillations. (b) Precipitation in rakutat and Cordova, $100 \mathrm{~km}$ east and west, respectively, of Seal River. (c) Local water speed. (d) Electrical conductivity.

\section{DISCUSSION}

Major precipitation events need to be considered when interpreting the stage record on the Seal River. Indeed, the first flood (event A) can be correlated with precipitation (Fig. 2b). Using the mean precipitation at Cordova and Yakutat (about $100 \mathrm{~km}$ to the west and east, respectively, of Bering Glacier) and ignoring orographic effects, an estimated $100 \mathrm{~mm}$ of rain fell during the 17-21 July period, representing $5 \times 10^{8} \mathrm{~m}^{3}$ of water for the entire Bering basin. In comparison, the rise in stage between 17 and 23 July corresponds to an increase in discharge that amounts to a water volume of only $10^{8} \mathrm{~m}^{3}$ above background throughput. (The computation of discharge and the uncertainties involved are discussed below.) Therefore, rainfall over this period probably contributed significantly to water storage in the system.

The second peak of the stage record (event B) corresponds to the spectacular end-of-July flood outburst from the eastern lobe of the terminus Molnia and others, $1994 a, b)$. Although the flood started abruptly on 27 July, according to eyewitness accounts, the discharge from Vitus Lake increased in earnest on 31 July, peaked on 5 August and ended approximately on 9 August. The expected damping of the tidal signal in the Seal River due to the substantial increase in discharge is evident during the flood. Whereas the rise in stage in the Seal River was at most $1.1 \mathrm{~m}$ above normal, Trabant and Molnia (1994) recorded a water-level rise of $4 \mathrm{~m}$ at Tsivat Lake, in the easternmost sub-basin of Vitus Lake close to the site of the spectacular outburst of water from the glacier terminus. Hence, our stage record at BS represents a highly attenuated signal of the Bering flood filtered by the proglacial lake complex.

Only the rising limb of the hydrograph was recorded for event $\mathrm{C}$, because of equipment failure. This increase in discharge was not weather-related. Temperatures were similar to those in the preceding period and no rain fell during, or within the two weeks preceding, the onset of the stage rise. Since the stage record was interrupted, it is instructive to examine water conductivity and speed records for complementary information on this event. These records, particularly the conductivity (Fig. 2d), show two periods (approximately 27 July-9 August and 15-23 August) with pronounced attenuation of tidal modulation. By analogy with the first period, which appears to coincide with well-documented event B, the second period that starts contemporaneously with stage event $\mathrm{C}$ is suggestive of a flood of similar magnitude and somewhat shorter duration than event B.

Little is known about where event C originated, except that it probably did not emanate from under the eastern lobe since the Tsivat lake-level record, which showed a $4 \mathrm{~m}$ rise during event $\mathrm{B}$ (personal communication from D.C. Trabant, 1995), revealed nothing unusual during event C. It appears, therefore, that event $\mathrm{C}$ originated from another part of the lobe. This would not be surprising since hydraulically isolated basins appear likely under Bering Glacier for two reasons. First, the basal topography can be inferred to a certain extent from the bathymetry of Vitus Lake, as both are produced by glacial erosion and deposition. Vitus Lake features seven distinct basins $>100 \mathrm{~m}$ in depth, separated by shallow sills Carlson and others, 1993). Secondly, the sparse information available on the basal topography of Bering Glacier shows that within tens of kilometers of the terminus, the bottom relief reaches several hundred meters and ice extends well below sea level according to an unpublished 1992 map (personal communication from B. Molnia, 1994). It follows that the timing and location of drainage events from each subglacial basin would be controlled by local topography, ice thickness and ice dynamics.

Detailed records of local water speed at BS show that speed peaked before the stage dropped halfway from high to low, and decreased monotonically thereafter until near high tide when the flow reversed direction, and Seal River waters flowed back into Vitus Lake. The speed record tends to be anticorrelated with stage until 27 July, the 
date of the onset of event $\mathrm{B}$, when the amplitude of tidal fluctuations starts to decrease, presumably because of increased discharge from Vitus Lake (Fig. 2c). Speed increases abruptly on 4 August, probably due to changes in local near-bank eddies, or other flow geometries resulting from increasing depth at the sampling site; speed peaks on 5 August. A more progressive increase in velocity occurs during event $\mathrm{C}$, after which velocity decreases to unprecedentedly low values. The velocity decrease can be associated with a lowering of lake level after the flood outburst and associated changes in local flow geometry at BS. High-water marks on the lake shore were about $1 \mathrm{~m}$ above lake-water level in early September. This decrease in velocity suggests that event C terminated by 23 August. We stress, however, that our interpretation of the qualitative speed record is highly speculative; other explanations could be offered for most of the "speed events", and parts of the records remain enigmatic. For example, we have no explanation for the large increase in water speed starting on 26 August and reaching an unprecedented maximum $4 \mathrm{~d}$ later.

The conductivity record illustrates well the complexity of water and solute transfer between Vitus Lake and the Gulf of Alaska. The early part of the record shows good correlation with tide (Fig. 3d). However, Cl concentrations in Seal River water samples reveal that before the flood that started on 27 July, sea water was an important component of the dissolved load at BS irrespective of stage (mean $\mathrm{Cl}^{-}$concentration of $760 \mathrm{mg} \mathrm{l}^{-1}$ during outflow). In contrast with the low conductivity of glacial water output throughout July before event B $\left(\sim 0.1 \mathrm{mS} \mathrm{cm}^{-1}\right)$, lake conductivity ranged from top to bottom between 2 and $3.2 \mathrm{mS} \mathrm{cm}^{i}$ Gray and others, 1994). Damping of tidally induced oscillations in conductivity begins in late July presumably due to increased flood discharge. The sudden increase in conductivity on 4 August (event B) suggests that flood waters caused mixing of relatively saline lake water. Conversely, the post-flood decrease in conductivity probably reflects mixing of dilute subglacial water into the lake. A similar sequence of events is reflected in the record after event $\mathrm{C}$; conductivity oscillates (seemingly haphazardly) about a reduced level starting on 24 August, thus further indicating termination of event C.

According to eyewitness accounts and satellite images, there was no sediment plume to the ocean or turbid water in the Seal River between the onset of the surge in the spring of 1993 and late June 1994. By 11 July, the surface of the Seal River was highly turbid. Suspended-sediment concentrations ranged from 1 to $3 \mathrm{~g} \mathrm{l}^{-1}$ and were greatest at ebb tide, when the flow was most vigorous. Comparison of depth-integrated samples collected at low tide with surface samples showed negligible vertical gradient in suspended load. Significant vertical concentration gradients may have existed, however, during slower flow. A cross-channel gradient in sediment concentration during fast flow was evident in depthintegrated and surface samples $\left(3.2 \mathrm{~g} \mathrm{l}^{-1}\right.$ near the thalweg vs $1.8 \mathrm{~g} \mathrm{l}^{-1}$ near BS). By 9 September, although the Seal River was still turbid, suspended-sediment concentrations had diminished considerably $\left(0.14 \mathrm{~g} \mathrm{l}^{-1}\right)$.

\section{FLOOD DISCHARGE}

Lacking a rating curve to relate discharge to stage, we unconventionally calculate discharge from our stage record assuming that during both low and high tides the flow in the Seal can be treated adequately as steady uniform flow in a rectilinear channel of rectangular crosssection (a good approximation for at least one bank). We compare calculated discharges at high and low tides with measured discharges to determine the principal unknown: the Manning roughness coefficient $n$, which characterizes the bed resistance $\left(n=0.028 \pm 0.003 \mathrm{~m}^{-\frac{1}{3}} \mathrm{~s}\right)$, which can then be used to calculate discharge from stage measurements. This determination of $n$ utilizes our stage measurements on the Seal River, estimates of tide levels at the mouth of the Seal based on tide records from Cordova and Yakutat, and Manning's equation. The greatest source of uncertainty in discharge calculations is

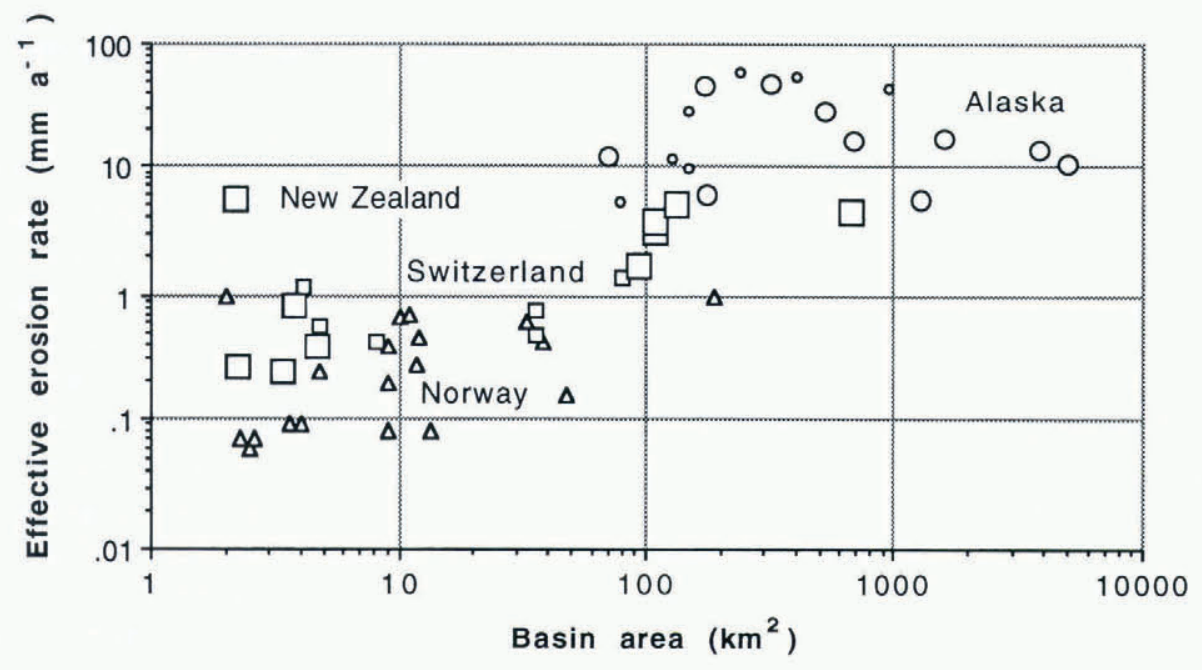

Fig. 3. Effective bedrock erosion rates, which include both bedrock erosion and sediment evacuation, marked according to region: southern Alaska (large circles refer to records representing deposition for over a decade to a century; small circles refer to shorter records), Swiss Alps (small squares), Norway/Svalbard (triangles) and other areas including New Zealand, Asia and Iceland (large squares). Modified from Hallet and others (in press). 
the lack of local tide data; uncertainties in stage and hydraulic geometry and Manning's $n$ are of secondary importance. Overall, we estimate that our calculated discharges are reliable to within about $20 \%$. To assess discharge for a period of several days or longer, we make the simplifying assumption that water surface slope varies sinusoidally with time due to tidal forcing, and compute the water discharge averaged over tide cycles.

The surface slope and hydraulic radius of the Seal River when the flow depth reached its peak during the clearest flood, event B at BS, correspond to a maximum discharge $1800 \mathrm{~m}^{3} \mathrm{~s}^{-1}$ above base flow $\left(1550 \mathrm{~m}^{3} \mathrm{~s}^{-1}\right)$. Integration of the flood hydrograph from 31 July to 9 August yields a water volume of $9.5 \times 10^{8} \mathrm{~m}^{3}$ for event B and an average discharge of $1100 \mathrm{~m}^{3} \mathrm{~s}^{-1}$ above base flow.

The above flood discharge has been calculated with Manning's $n$ obtained from base flow conditions; the change in relative roughness of the channel due to increased flow depth during the flood could affect this result significantly. Effective drowning of roughness elements can be assessed by computing the average wall roughness height $\epsilon$ with the Manning roughness correlation $\left(f=8 g n 2 / R^{\frac{1}{3}}\right.$, where $f$ is the Darcy-Weissback friction factor, $g$ is the gravitational acceleration and $R$ is the hydraulic radius) and Colebrooks' relation applied to fully rough flow $\left(f=[2 \log (14.8 R / \epsilon)]^{-2}\right)$ (White, 1994). The average wall roughness $(0.18 \mathrm{~m})$ is then used in conjunction with the increased flow depth to compute a new Manning's $n$ applicable to event $\mathrm{B}$. This correction increases flood-discharge calculations by $<1 \%$, which is negligible considering the other uncertainties involved. Moreover, the effect of drowning bed roughness is likely to be partly offset by heavy vegetative cover on the western bank.

The volume of water released during event B amounts to a layer $0.38 \mathrm{~m}$ thick when spread over the $2500 \mathrm{~km}^{2}$ of Bering Glacier involved in the surge since the 1993/94 winter. This figure could underestimate the water stored in the system during the period of rapid basal motion (prior to summer 1994) because the subglacial hydraulic system may have been only partially drained. One would expect event B to evolve similarly to other glacially derived floods. Outburst hydrographs from subglacial and glacier-dammed lakes are characterized by rapid rises due to the swift enlargement of subglacial conduits and by very steeply falling limbs due to rapid creep closure as water pressure decreases below flotation (e.g. Clague and Mathews, 1973; Desloges and others, 1989; Paterson, 1994). However, preliminary finite-difference flow-routing of flood waters from the eastern lobe of Bering Glacier through the proglacial lakes and their outlets (Tsivat, Tsiu and Vitus Lakes) to the Seal River show that a jökulhlaup with a highly asymmetrical hydrograph into Tsivat Lake cannot account for the overall symmetry in the rise and fall of the hydrograph recorded in the Seal River (Figs 1 and 3). The lag in hydrograph rise at Seal River (27-31 July) can be accounted for by the presence of reservoirs downstream of the area where flood waters were observed to emanate from the glacier.

The duration and symmetry of the hydrograph is more suggestive of drainage through an extensive distributed subglacial hydraulic system than drainage from large subglacial cavities, which would tend to be more like jökulhlaups. If we assume event B drained the entire area of intense crevassing during the surge $(25 \mathrm{~km}$ by $100 \mathrm{~km}$ ) at its southeastern corner, and further assume the hydrological response of the subglacial channel network to be similar to that of a subaerial arborescent drainage network, we can estimate typical water-flow speeds under the glacier, as well as the collective crosssectional area of subglacial water-filled conduits. First, we would expect the flood to peak when the bulk of the water draining from the dominant subglacial reservoirs, which would tend to be located at intermediate positions in the drained area, reaches the outlet (rather than at extreme positions either nearest to or farthest from the terminus). As the water flux peaked $5 \mathrm{~d}$ after the beginning of the rise in the hydrograph, if we use an order-of-magnitude estimate of $50 \mathrm{~km}$ (the approximate midpoint of the crevassed area) for the distance between the most extensive subglacial reservoirs and the glacier outlet at Tsivat Lake (Fig. 1), the mean longitudinal flow velocity was about $0.12 \mathrm{~m} \mathrm{~s}^{-1}(50 \mathrm{~km}$ in $5 \mathrm{~d})$. Secondly, we use this water-velocity estimate together with the average flood discharge previously calculated $\left(1100 \mathrm{~m}^{3} \mathrm{~s}^{-1}\right)$ to determine the collective cross-sectional area of basal conduits; simply dividing flood discharge by the mean water velocity yields the effective basal conduit area: $0.92 \times$ $10^{4} \mathrm{~m}^{2}$. Considering a system distributed over the entire $25 \mathrm{~km}$ width of the glacier, we arrive at a mean waterlayer thickness of $0.37 \mathrm{~m}$. If either the cavity system occupied only half of the bed or only half of the surging part of Bering Glacier was drained by event B, the representative basal water depth would have been $0.74 \mathrm{~m}$. Although the assumptions inherent in these calculations are considerable, we note the substantial agreement between the effective water-layer thickness estimate $(0.38 \mathrm{~m})$ based on total water volume drained in event $B$ and the estimate $(0.37 \mathrm{~m})$ based on the estimated subglacial water velocity and discharge. These results are consistent with other studies that report effective basal water thickness of a fraction of a meter (Kamb, 1987; Humphrey and Raymond, 1994; Walder and Driedger, 1995).

\section{SEDIMENT FLUX AND EROSION}

We estimate sediment flux using the suspended-sediment concentrations measured manually during July 1994. Bedload transport can be ignored because, except for limited debris transported in icebergs that float to the outlet of Vitus Lake, coarse-grained material emanating from the glacier tends to settle in Vitus Lake, and hence does not have access to the Seal River. We assume that only negligible sediment transport occurs outside the 3 month ablation season. If we use an average concentration of $2 \mathrm{~g} \mathrm{l}^{-1}$ for non-flood stage, and $10 \mathrm{~g} \mathrm{l}^{-1}$ during events $\mathrm{B}$ and $\mathrm{C}\left(10 \mathrm{~g} \mathrm{l}^{-1}\right.$ is about one-third of the maximum suspended load during floods at Variegated Glacier), the total mass of sediment transported through the Seal during the ablation season is $3 \times 10^{10} \mathrm{~kg}$. This corresponds to $2 \mathrm{~mm}$ of erosion over the entire drainage basin (assumed rock density: $2850 \mathrm{~kg} \mathrm{~m}^{-3}$ ). Although this estimate is rough (i.e. it could be doubled if the floodwater concentrations were increased to $30 \mathrm{~g} \mathrm{l}^{-1}$ ), it is 
greater than the worldwide average for mountainous regions $\left(0.8 \mathrm{~mm} \mathrm{a}^{-1}\right)$, which is derived from sediment yields from over 150 mountain basins, as tabulated by Milliman and Syvitski (1992).

Thus, sediment transport from Vitus Lake into the Gulf of Alaska in the Seal is very considerable, amounting to nearly $30 \mathrm{Mt}$ in 1994. Nevertheless, this is most probably only a small fraction of the sediment produced by Bering Glacier during this time period. For periods extending from a few years to nearly a century, sediment yields from other large glaciers of coastal southern Alaska (Hallet and others, 1996) typically correspond to extraordinarily high effective rates of erosion of 10 $100 \mathrm{mma}^{-1}$ (Fig. 3). Erosion at Bering Glacier is most likely to be at least as rapid, because a substantial part of the glacier is underlain by easily eroded Plio-Pleistocene sediments (Yakataga Formation), and the varied bedrock in the rest of the basin is characteristic of the region. More importantly for the 1994 period, the rate of sediment production is very likely to correspond to the upper end of the $10-100 \mathrm{mma}^{-1}$ range of effective rates of erosion because it included a period of rapid ice motion near the end of the surge. This inference is supported by work at Variegated Glacier, also situated in southern Alaska, by Humphrey and Raymond (1994). They proposed that two-thirds of the total bed erosion for a 17 year period occurred during the 2 year surge, assuming that no longterm storage occurred at Variegated Glacier and that suspended-sediment output scaled directly with sliding velocity. Thus we suggest that during the 1993-94 surge, only a minor fraction of the sediment produced by Bering Glacier currently reached the Pacific Ocean, and hence that the bulk of the sediment is being stored either subglacially or, more likely, in the proglacial lake complex, where massive sedimentation has been documented (personal communication from B. F. Molnia, 1995).

\section{CONCLUSIONS}

Two major floods were released from Bering Glacier during the summer of 1994 after ice velocities had decreased to a fraction of the maximum surging velocity. Computation of water volumes involved in the floods and their duration allowed general characterization of the subglacial hydraulic system as a pervasive network of cavities and conduits that collectively contains the equivalent of a water layer $0.3-0.5 \mathrm{~m}$ thick over the entire surging part of Bering Glacier.

Preliminary interpretation of results confirms that the sediment flux through the Seal River during the 1994 melt season was very small compared to expected rates of erosion generated by fast ice motion during the surge. Vitus Lake has functioned as an efficient sediment trap since the previous surge and will continue to do so unless another surge pulse causes Bering Glacier to close in on the remainder of the lake, thus forcing sediment to be routed to the Pacific. Further monitoring of sedimentation in Vitus Lake is most promising, as it will permit computation of a sediment budget covering an entire surge/non-surge cycle so that erosion rates averaged over a vast area can be determined over a range of dynamic behavior.

\section{ACKNOWLEDGEMENTS}

The University of Washington Royalty Research Fund provided funding for this study. We wish to thank B. Molnia who provided logistical support as well as a stream of valuable information; M. Herder for his companionship, assistance and his boat without which none of this work would have been possible; J. Gray, R. Hart and D. Trabant for sharing data with us; and many other individuals for their help at various stages of the study: B. Benedict, B. Bruner, H. Conway, W. Harrison, A. Post, C. Raymond, R. Sletten and D. Trabant. We thank D. Collins, A. Fountain and D. Lawler for many very helpful comments on an earlier version of this paper.

\section{REFERENGES}

Bogen, J. 1989. Glacial sediment production and development of hydroelectric power in glacierized areas. Ann. Glaciol., 13, 6-11.

Calles, B. and U. M. Calles. 1990. Temperature correction of electrical conductivity values. Earth Surface Processes and Landforms, 15, 673678.

Carlson, P. R., B. F. Molnia and A. Post. 1993. Pre-Holocene and Holocene crosional and depositional history of Bering Trough and Vitus Lake, Bering Glacier, Alaska. [Abstract] EOS, 74 43), Supplement, 292.

Clague, J.J. and W. H. Mathews. 1973. The magnitude of jökulhlaups. 7. Glaciol., 12 (66), 501-504.

Collins, D. N. 1978. Hydrology of an alpine glacier as indicated by the chemical composition of meltwater. Z. Gletscherkd. Glazialgeol., 13 2), 1977, 219238.

Desloges, J. R., D. P. Jones and K. E. Ricker. 1989. Estimates of peak discharge from the drainage of ice-dammed Ape Lake, British Columbia, Canada. J. Glaciol., 35 121), 349-354.

Gray, J. R., R.J. Hart and B. F. Molnia. 1994. 1994 changes in physical and sedimentary characteristics of proglacial Vitus Lake resulting from the surge of Bering Glacier, Alaska. [Abstract] EOS, 75 (4), Supplement, 63.

Gurnell, A. M. 1987. Fluvial sediment vield from alpine, glacierized catchments. In Gurnell, A. M. and M.J. Clark, eds. Glacio-fluvial sediment transfer: an Alpine perspective. Chichester, etc., John Wiley and Sons, $415-420$.

Hallet, B., L. E. Hunter and J. Bogen. 1996. Rates of erosion and sediment evacuation by glaciers: a review of the evidence. Global and Planetary Change. 12, 213235

Harbor, J. and J. Warburton. 1993. Relative rates of glacial and nonglacial erosion in Alpine environments. Arct. Alp. Res., 25 1) , $1-7$.

Humphrey, N.F. and C. F. Raymond. 1994. Hydrology, erosion and sediment production in a surging glacier: Variegated Glacier. Alaska. $1982-83$. J. Glaciol., 40 136), $539-552$.

Humphrey, N., C. Raymond and W. Harrison. 1986. Discharges of turbid water during mini-surges of Variegated Glacier, Alaska, U.S.A. J. Glaciol., 32 111$), 195-207$.

Kamb, B. 1987. Glacier surge mechanism based on linked-cavity configuration of the basal water conduit system. 7. Geophys. Res.. 92 B9), $9083-9100$.

Lagoe, M., C. Eyles, N. Eyles and C. Hale. 1993. Timing of Late Cenozoic tidewater glaciation in the far North Pacific. Geol. Soc. Am. Bull., 105, 1.542-1560.

Lawler, D., M. Dolan, H. Tómasson and S. Zóphóniasson. 1992. Temporal variability of suspended sediment flux from a subarctic glacial river, southern Iceland. International Association of Hydrological Sciences Publication 210 Symposium at Oslo 1992 - Erosion and Sediment Transport Monitoring Programmes in River Basins), 233-243.

Milliman, J. D. and J. P. M. Syvitski. 1992. Geomorphic/tectonic control of sediment discharge to the ocean: the importance of small mountainous rivers. J. Geol., 100, $525-544$.

Molnar, P. and P. England. 1990. Late Cenozoic uplift of mountain ranges and global climate change: chicken or egg? Vature, $\mathbf{3 4 6} 6279$. 2934.

Molnia, B, 1993. Major surge of the Bering Glacier. EOS, 74 29), 321 322.

Molnia, B. F., A. Post, D. C. Trabant and R. M. Krimmel. 1994a. The 
1993-94 surge of Bering Glacier, Alaska: an overview. [Abstract] EOS, 75 (44), Supplement, 62.

Molnia, B. F., A. Post and P.J. Fleisher. 1994b. Unusual hydrological events related to the 1993-94 surge of Bering Glacier, Alaska. [Abstract] EOS, 75 (44), Supplement, 63.

Paterson, W. S. B. 1994. The physies of glaciers. Third edition. Oxford, etc., Elsevier.

Plafker, G., T. Hudson, K. Rubin and D. Dixon. 1980. Holocene marine terraces and uplift history in the Yakataga seismic gap near Icy Cape, Alaska. U.S. Geol. Surv. Circ. 844, 111-115.

Powell, R.D. and B.F. Molnia. 1989. Glacimarine sedimentary processes, facies and morphology of the south-southeast Alaska Shelf and fjords. Mar. Geol., 85(2-4), 359-390.
Raymo, M.E. and W.F. Ruddiman. 1992. Tectonic forcing of late Cenozoic climate. Nature, 359 6391), 117-122.

Trabant, D. C. and B.F. Molnia. 1994. Ice speed, ice thickness, and proglacial-lake stage and turbidity trends at the surging Bering Glacier, Alaska. [Abstract] EOS, $75(44)$, Supplement, 63.

Viens, R.J. 1995. Dynamics and mass balance of temperate tidewater calving glaciers of southern Alaska. M.Sc. thesis, University of Washington.)

Walder, J. S. and C. L. Driedger. 1995. Frequent outburst floods from South Tahoma Glacier, Mount Rainier, U.S.A.: relation to debris flows, meteorological origin and implications for subglacial hydrology. F. Glaciol., 41(137), 1-10.

White, F. M. 1994. Fluid mechanics. New York, McGraw-Hill. 